\title{
Prototype Pembelajaran Pemanfaatan Energi Baru Terbarukan Berbasis Energi Surya
}

\author{
Samsurizal $^{1}$; Septiannissa Azzahra ${ }^{2}$; Christiono ${ }^{3}$; Miftahul Fikri ${ }^{4}$; \\ Hastuti Azis ${ }^{5}$; Agus Yogianto ${ }^{6}$ \\ 1,2,3,5,6 Program Studi Teknik Elektro, Institut Teknologi PLN \\ ${ }^{4}$ Program Studi Teknologi Listrik, Institut Teknologi PLN \\ ${ }^{1}$ samsurizal@itpln.ac.id
}

\begin{abstract}
The use of renewable energy (EBT) is increasing to achieve the target of $23 \%$ by 2025. There needs to be a variety of preparations in welcoming the transition of fossil-based energy to renewable energy. One of them is by improving the quality of human resources that excel in developing the use of renewable energy in Indonesia. Through the Electrical Engineering PkM Team IT-PLN had the opportunity to provide counseling or education to the academic community of MA Al-Khairiyah Rancaranji. The activity is in the form of learning the installation of solar power plant components and the utilization of solar energy in the form of prototype portable plts. The learning improved students' understanding of renewable energy and was able to assemble photovoltaic system components into prototype portable plts with a capacity of $100 \mathrm{WP}$. Then the tool is tested using a lamp load of 9 watts to find out the amount of current and voltage produced. From this activity, it can be known that the students of MA Al-Khairiyah Rancaranji are very enthusiastic in knowing about renewable energy and can apply it in the surrounding environment.
\end{abstract}

Keywords: Renewable Energy, Solar Energy, Prototype, Education

\begin{abstract}
ABSTRAK
Penggunaan energi baru terbarukan (EBT) semakin ditingkatkan guna mengupayakan pencapaian target sebesar $23 \%$ pada tahun 2025. Perlu berbagai persiapan dalam menyambut transisi energi dari berbasis fosil menuju energi baru terbarukan. Salah satunya dengan meningkatkan kualitas sumber daya manusia yang unggul dalam mengembangkan penggunaan energi terbarukan di Indonesia. Melalui Tim PkM Teknik Elektro IT-PLN berkesempatan memberikan penyuluhan atau edukasi kepada civitas akademik MA Al-Khairiyah Rancaranji. Kegiatan tersebut berupa pembelajaran pemasangan komponen-komponen pembangkit listrik tenaga surya dan pemanfaatan energi surya dalam bentuk prototype PLTS portable. Pembelajaran tersebut meningkatkan pemahaman siswa-siswi tentang energi baru terbarukan dan mampu merangkai komponen sistem fotovoltaik menjadi prototype PLTS portable dengan kapasitas 100 WP. Kemudian alat tersebut diuji coba dengan menggunakan beban lampu 9 watt untuk mengetahui besaran arus dan tegangan yang dihasilkan. Dari kegiatan tersebut dapat diketahui bahwa siswa-siswi MA Al-Khairiyah Rancaranji sangat antusias dalam mengenal tentang energi baru terbarukan dan dapat menerapkannya di lingkungan sekitar.
\end{abstract}

Kata kunci: Energi Terbarukan, Energi Surya, Prototype, Pembelajaran 


\section{PENDAHULUAN}

Pemerintah mengatakan akan terus mengupayakan pencapaian target bauran energi baru terbarukan (EBT) sebesar 23\% pada 2025 meski hingga 2020 capaiannya baru sebesar 11,5\% [1]. Pemenuhan kebutuhan energi listrik saat ini masih bergantung pada sumber energi fosil yang ketersediaanya terbatas. Oleh karena itu dimasa mendatang pemanfaatan sumber energi terbarukan merupakan alternatif yang perlu terus dikembangkan [1][2].

Tim PkM Teknik Elektro Fakultas Ketenagalistrikan dan Energi Terbarukan IT-PLN yang terdiri dari dosen dan mahasiswa berkesempatan mengunjungi MA Al-Khairiyah Rancaranji untuk memberikan edukasi/penyuluhan tentang pemanfaatan energi baru terbarukan khususnya energi surya[4][5]. Sebelumnya telah melaksanakan edukasi tentang energi baru terbarukan dan workshop mengenai pemanfaatan energi surya selanjutnya melaksanakan instalasi prototype PLTS portable sebagai media pembelajaran secara praktik. Kemudian melakukan uji coba pengukuran arus dan tegangan yang dihasilkan oleh panel surya dengan kapasitas 100 WP [12].

Dengan melihat situasi tersebut maka pada kegiatan PkM tahun ini kami mengangkat tema mengenai "Implementasi Pemanfaatan Energi Baru Terbarukan Berbasis Energi Surya Sebagai Prototype Pembelajaran pada MA Al-Khairiyah Rancaranji" sehingga akan dapat membantu pihak Sekolah Menengah Atas atau Madrasah Aliyah dalam hal melihat wujud asli dari penerapan Prototype PLTS Portable yang bisa digunakan sebagai media pembelajaran siswa-siswi, kegiatan ekstrakulikuler juga dapat digunakan dalam skala kecil dilingkungan sekolah [9].

Kegiatan PkM ini disampaikan oleh dosen dan mahasiswa Institut Teknologi PLN dan terlihat siswa siswi MA Al-Khairiyah Rancaranji sangat bersemangat mengikuti materi tentang energi baru terbarukan. Dengan adanya kegiatan ini peserta dapat mengetahui pemanfaatan energi baru terbarukan dalam menunjang aktivitas masyarakat. Menindaklanjuti kegiatan tahun sebelumnya dirasi perlu di buatkan prototype PLTS Portable sebagai pembelajaran di lingkungan MA AlKhairiyah Rancaranji agar bisa dilihat secara fisik sebagai media praktek maupun dimanfaatkan dalam lingkup yang kecil.

Pembelajaran mengenai pemanfaatan energi baru terbarukan perlu digalakan kepada seluruh lapisan masyarakat khususnya akademisi muda [10][11]. Hal ini untuk mempersiapkan generasi penerus bangsa dalam mengembangkan energi baru terbarukan yang memiliki potensi sangat besar di Indonesia. Melalui kegiatan PkM yang diadakan oleh IT-PLN diharapakan masyarakat menjadi semakin familiar tentang penggunaan PLTS sebagai salah satu bentuk pemenuhan kebutuhan energi masyarakat dengan memanfaatkan energi baru terbarukan berupa sinar matahari.

\section{METODE}

Diperlukan metode pelaksanaan kegiatan agar kegiatan yang dilakukan terarah dan terencana. Berikut ini adalah tahapan pelaksanaan kegiatan pengabdian kepada masyarakat di Ma Al-Khairiyah Rancaranji dalam bentuk diagram alir: 


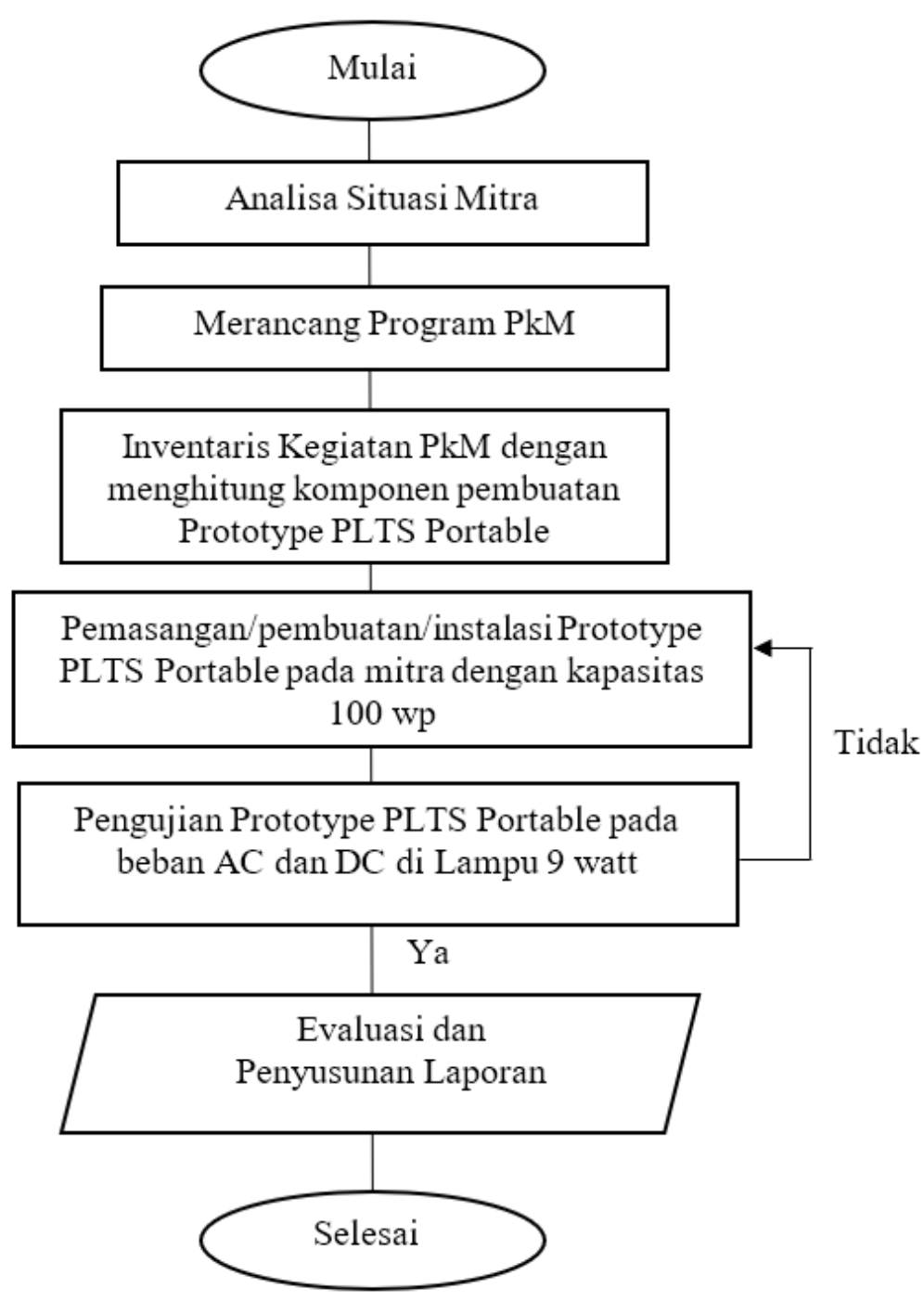

Gambar 1. Diagram Alir Kegiatan PkM

\subsection{Prinsip Dasar Pembangkit Listrik Tenaga Surya (PLTS)}

Berdasarkan SNI 8395:2017, PLTS adalah sistem pembangkit listrik yang energinya bersumber dari radiasi matahari melalui konversi sel fotovoltaik. Sistem fotovoltaik mengubah radiasi sinar matahari menjadi listrik [2]. Semakin tinggi intensitas radiasi (iradiasi) matahari yang mengenai sel fotovoltaik, semakin tinggi daya listrik yang dihasilkannya [3][4][5]. Karena listrik seringkali dibutuhkan sepanjang hari, maka kelebihan daya listrik yang dihasilkan pada siang hari disimpan di dalam baterai sehingga dapat digunakan kapanpun untuk berbagai alat listrik.

Tabel 1. Jenis-Jenis PLTS

\begin{tabular}{|l|l|l|l|}
\hline & \multicolumn{1}{|c|}{ PLTS off-grid } & \multicolumn{1}{c|}{ PLTS on-grid } & \multicolumn{1}{c|}{ PLTS Hybrid } \\
\hline Deskripsi & Sistem PLTS yang output & Bisa beroperasi tanpa & Gabungan dari sistem \\
& daya listriknya secara & baterai, karena output & PLTS dengan \\
& mandiri menyuplai listrik & listriknya disalurkan ke & pembangkit yang lainnya \\
& ke jaringan distribusi & jaringan distribusi yang & (mis. PLTD (Pembangkit \\
& pelanggan atau tidak & telah disuplai pembangkit & Listrik Tenaga Disel), \\
\hline
\end{tabular}




\begin{tabular}{|l|l|l|l|}
\hline & $\begin{array}{l}\text { terhubung dengan } \\
\text { jaringan listrik PLN. }\end{array}$ & $\begin{array}{l}\text { lainnya (mis. Jaringan } \\
\text { PLN). }\end{array}$ & $\begin{array}{l}\text { PLTB (Pembangkit } \\
\text { Listrik Tenaga Bayu)). }\end{array}$ \\
\hline Baterai & $\begin{array}{l}\text { Ya, supaya bisa } \\
\text { memberikan suplai listrik } \\
\text { sesuai kebutuhan beban. }\end{array}$ & Tidak. & $\begin{array}{l}\text { Bisa off-grid (pakai } \\
\text { baterai) atau on-grid } \\
\text { (tanpa baterai). }\end{array}$ \\
\hline Manfaat & $\begin{array}{l}\text { Untuk menjangkau } \\
\text { daerah yang belum ada } \\
\text { jaringan listrik PLN. }\end{array}$ & $\begin{array}{l}\text { Untuk berbagi beban atau } \\
\text { mengurangi beban } \\
\text { pembangkit lain yang } \\
\text { terhubung pada jaringan } \\
\text { yang sama. }\end{array}$ & $\begin{array}{l}\text { Memaksimalkan } \\
\text { penyediaan energi dari } \\
\text { berbagai potensi sumber } \\
\text { daya daerah. }\end{array}$ \\
\hline
\end{tabular}

\subsection{Komponen Utama Sistem Fotovoltaik}

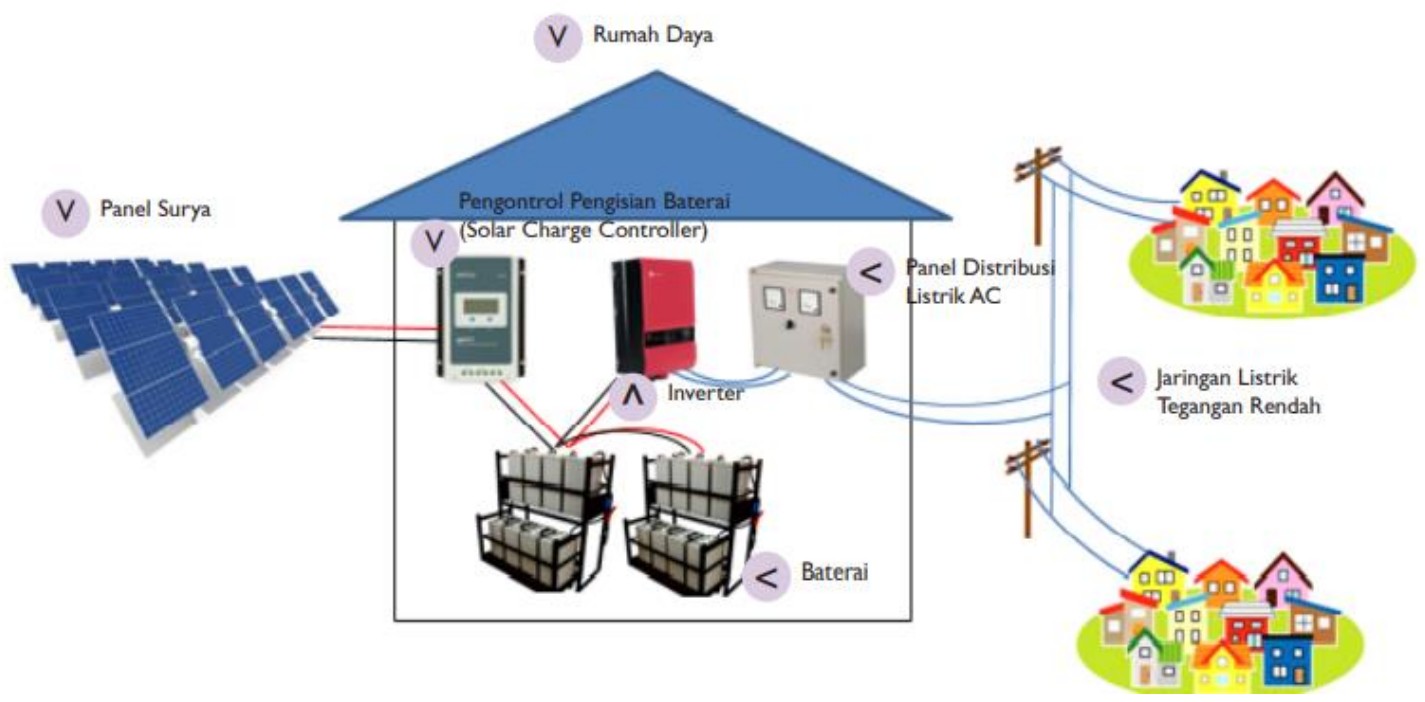

Gambar 2. Diagram Komponen PLTS

\section{Panel Surya}

Dalam sebuah modul surya, terdapat sel-sel fotovoltaik tempat terjadinya efek fotovoltaik. Apabila beberapa modul surya dirangkai, maka akan terbentuk suatu sistem pembangkit listrik tenaga surya. Kualitas sebuah modul surya, antara lain dinilai berdasarkan efisiensinya untuk mengkonversi radiasi sinar matahari menjadi listrik DC. Secara umum, sel fotovoltaik terbuat dari material jenis crystalline dan non-crystalline (film tipis) [8][9]. Untuk jenis crystalline, terbagi atas tipe mono-crystalline dan tipe poly-christalline, dengan efisiensi konversi sekitar $12-20 \%$ [10][11]. Berikut perbandingan antara poly-crystalline dan mono-crystalline: 
Tabel 2. Panel Surya

\begin{tabular}{|l|l|l|}
\hline & Mono-crystalline & \multicolumn{1}{|c|}{ Poly-Crystalline } \\
\hline $\begin{array}{l}\text { Ilustrasi } \\
\text { Sodul }\end{array}$ & & \\
\hline Biaya & Lebih Mahal & Lebih Murah \\
\hline Efisiensi & $15-20 \%$ & $1-2 \%$ lebih rendah dari mono- \\
& & crystalline \\
\hline
\end{tabular}

2. Inverter

Inverter pada sistem plts adalah sebuah komponen atau alat pada sistem solar panel yang berfungsi untuk merubah arus DC (Direct Current) yang dihasilkan oleh panel surya menjadi arus listrik AC (Alternating Current) [12][13]. Selain bisa digunakan untuk kebutuhan rumah tangga, listrik AC yang dihasilkan inverter juga berguna untuk mengimpor kelebihan daya yang dihasilkan sistem panel surya yang kita hasilkan ke jaringan PLN untuk dapat dimanfaatkan kembali sebagai kredit jika sistem panel surya berhenti bekerja di malam hari.

3. Solar Charge Controller atau Solar Charge Regulator Solar Charge Controller (SCC), atau Solar Charge Regulator (SCR), berfungsi membatasi arus listrik yang masuk maupun keluar dari baterai. SCC/SCR mencegah pengisian daya (charging) yang berlebihan serta melindungi baterai dari tegangan berlebih. Selain itu, SCC/SCR juga mencegah baterai agar energi listrik yang tersimpan di dalamnya tidak terkuras (discharged) sampai habis [6][7]. Beberapa tipe SCC/SCR dapat secara otomatis dan terkontrol memutus tegangan suplai beban, untuk mencegah baterai dari kondisi deep discharge yang bisa memperpendek umur pakai baterai.

4. Baterai

Baterai merupakan salah satu cara penyimpanan daya yang paling umum digunakan. Baterai yang paling tepat untuk sistem PLTS adalah yang memiliki jenis karakter Deep Discharge. Baterai jenis ini bisa di-discharge energi listriknya hingga tersisa sekitar $20 \%$ dari kapasitas simpan baterai. (Baterai untuk starting kendaraan bermotor umumnya hanya boleh di-discharge hingga tersisa $80 \%$ dari kapasitas simpan baterai. Jika di-discharge melebihi kapasitas tersebut, maka umur baterai akan lebih singkat) [6][13].

\subsection{Prototype PLTS Portable}

Bentuk kegiatan yang akan dilakukan adalah dengan pembuatan prototype PTLS Portable dilingkungan mitra agar bisa dijadikan bahan pembelajaran dan praktek oleh siswa/i serta civitas akademik sekolah, juga dapat digunakan dalam skala kecil dilingkungan MA Al-Khairiyah Rancaranji. Setelah dilakukan pembuatan prototype dilanjutkan dengan melakukan pengecekan dan pengujian peralatan instalasi yang sudah dibuat selanjutnya siswa-siswi diberikan kesempatan untuk melakukan perakitan dengan didampingi oleh mahasiswa dan dibawah arahan para dosen. Prototype 
yang dibuat juga akan di lengkapi dengan bagan alur/skema pemanfaatan energi terbarukan berbasis surya seperti yang ditunjukkan gambar .3.

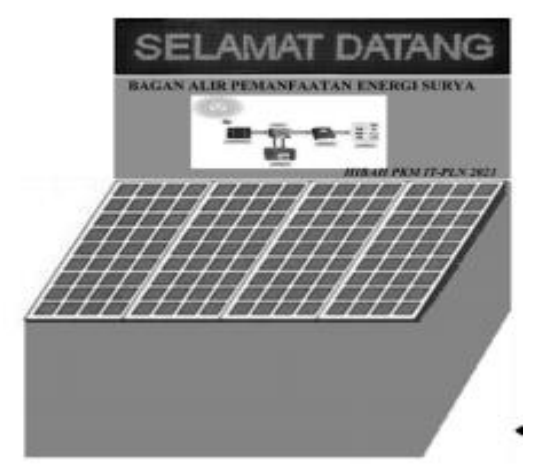

Gambar 3. Prototpye PLTS Portable

\section{HASIL DAN PEMBAHASAN}

\subsection{Kunjungan Tim PkM}

Tim PkM Teknik Elektro Fakultas Ketenagalistrikan dan Energi Terbarukan Institut Teknologi PLN telah melakukan kunjungan ke MA Al-Khairiyah Rancaranji, Kecamatan Padarincang, Kabupaten Serang, Banten. Pada tanggal 25 November 2020. Kunjungan yang dilakukan adalah kunjungan pendahuluan yang bertujuan untuk mensurvei lokasi mitra. Kemudian membahas langkah selanjutnya dalam pelaksanaan program pengabdian pada masyarakat $(\mathrm{PkM}) \mathrm{di}$ MA Al-Khairiyah Rancaranji. Seperti yang ditunjukkan pada gambar 4.
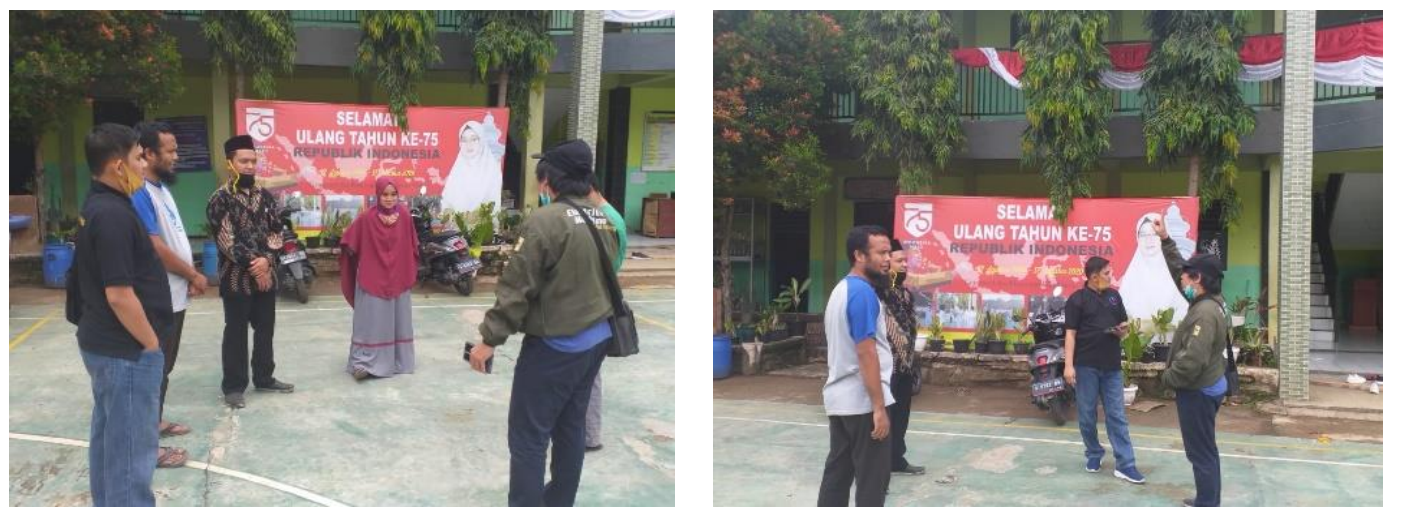

Gambar 4. Survei Lokasi Mitra

\subsection{Kegiatan PkM}

Kegiatan PkM diawali dengan pembukaan dan sambutan oleh Tim PkM Fakultas Ketenagalistrikan dan Energi Terbarukan Institut Teknologi PLN kepada Kepala Sekolah, Guru dan Siswa-Siswi MA Al-Khairiyah Rancaranji. Terlihat bahwa siswa siswi MA Al-Khairiyah Rancaranji sangat antusias saat mengikuti rangkaian kegiatan. Seperti yang ditunjukkan pada gambar .5. 


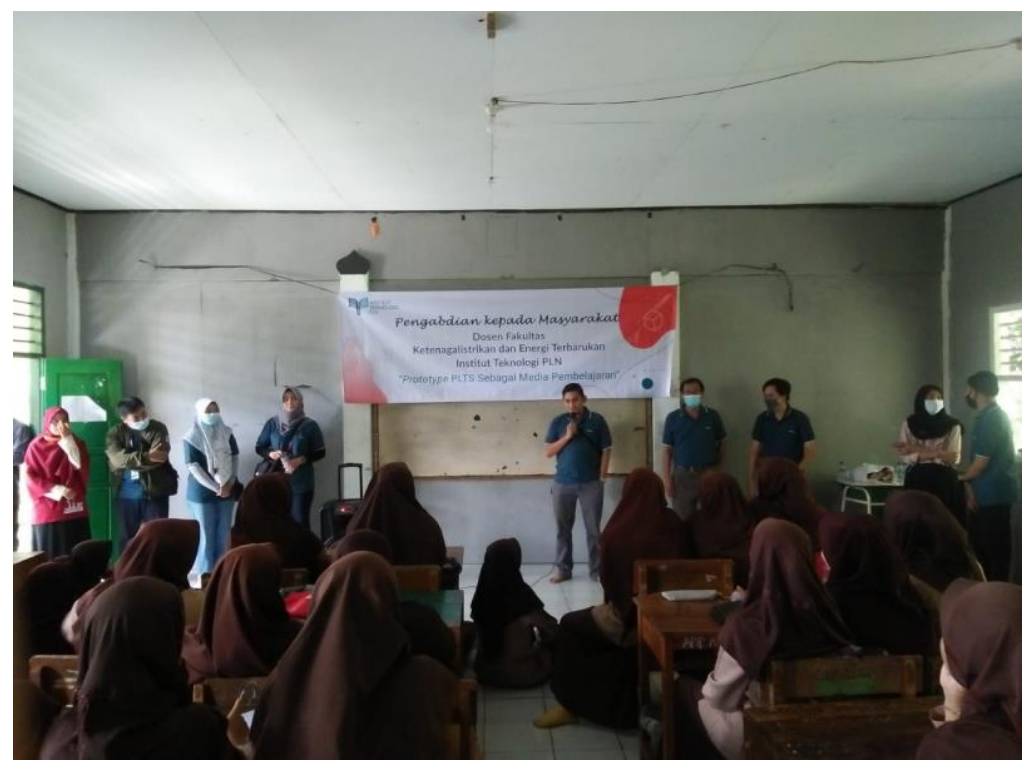

Gambar 5. Sambutan dan Pembukaan Kegiatan PkM

Kegiatan selanjutnya dimulai dengan edukasi mengenai energi baru terbarukan (EBT) kepada siswa siswi MA Al-Khairiyah Rancaranji. Dalam memperkenalkan energi baru terbarukan, tim PkM Fakultas Ketenagalistrikan dan Energi Terbarukan Institut Teknologi PLN melakukan kegiatan penyuluhan tentang energi baru terbarukan, khususnya mengenai Pembangkit Listrik Tenaga Surya (PLTS), komponen apa saja yang digunakan, bagaimana cara kerja PLTS tersebut, dan pemanfaatan energi baru terbarukan dalam kehidupan sehari-hari kepada siswa siswi MA Al-Khairiyah Rancaranji

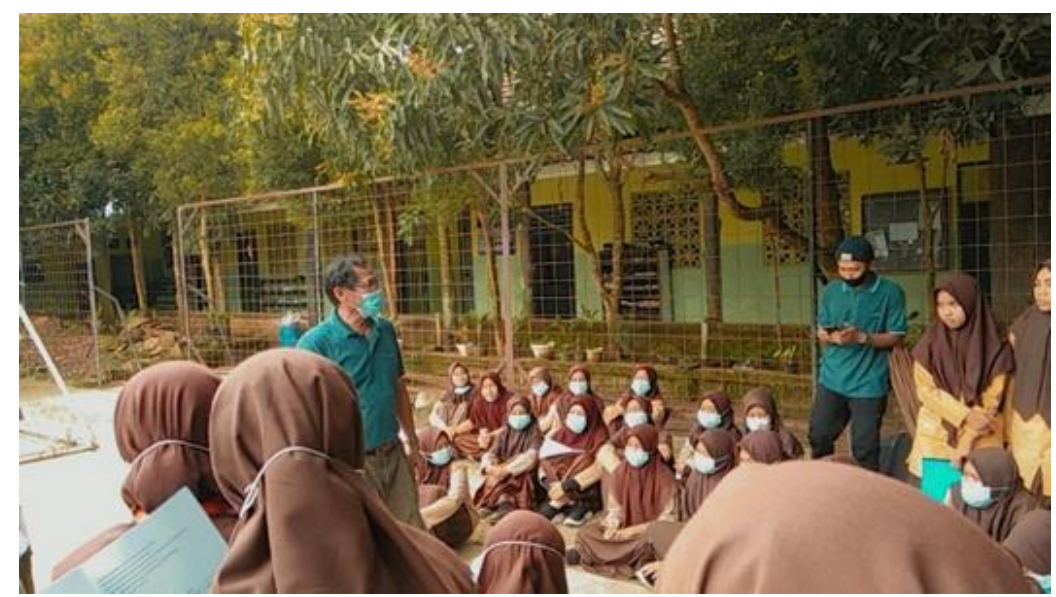

Gambar 6. Edukasi dan Pengenalan Penerapan EBT

Dapat diketahui bahwa sebagian besar sudah memahami dengan baik tentang energi baru terbarukan khususnya PLTS yang dapat dilihat dari antusias siswa siswi MA Al-Khairiyah Rancaranji saat menerima materi presentasi dan aktif dalam bertanya maupun menjawab pertanyaan yang diberikan oleh tim PkM.

Kegiatan selanjutnya yaitu pelaksanaan pembuatan dan instalasi Prototype PLTS Portable yang dilaksanakan di halaman sekolah MA Al-Khairiyah Rancaranji. Kegiatan ini ditujukkan agar siswa siswi dapat melihat secara langsung bagaimana proses perakitan atau pemasangan Prototype PLTS Portable sesuai dengan teori yang sudah dijelaskan pada saat penyuluhan dikelas. 


\subsection{Pembuatan dan Instalasi PLTS Portable}

Siswa siswi MA Al-Khairiyah Rancaranji juga diberikan modul pembelajaran tentang PLTS supaya selain menyimak pemasangan dan cara kerja PLTS Portable tersebut, diharapkan juga siswa siswi dapat menghitung besar tegangan, arus dan daya yang dihasilkan oleh PLTS tersebut. Kegiatan ini diawali dengan penjelasan tentang pembangkit listrik tenaga surya. Kemudian jenis-jenis solar panel yang dapat digunakan seperti monocrystaline, polycrystaline, dan panel thin film. Selanjutnya dijelaskan juga tentang komponen-komponen PLTS yang lain seperti inverter, batterai, controller dll. Sehingga dapat bekerja sesuai dengan fungsinya. Sesuai yang ditunjukkan pada gambar 7 .

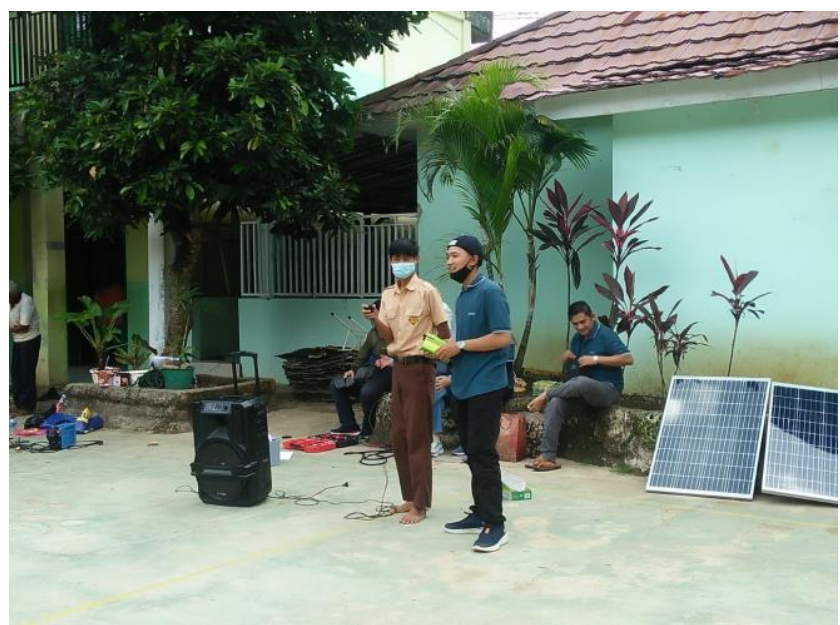

Gambar 7. Penjelasan tentang komponen PLTS

Selanjutnya siswa-siswi MA Al-Khairiyah Rancaranji diberi kesempatan untuk menjawab pertanyaan dari Tim PkM mengenai materi PLTS yang sudah didapat saat penyuluhan dikelas dan saat melihat komponennya secara langsung. Seperti yang terlihat pada gambar 8 .

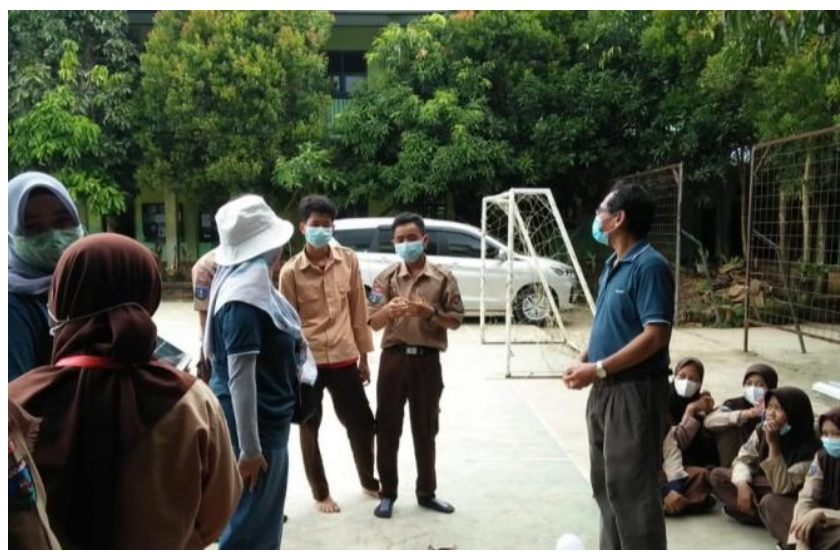

Gambar 8. Siswa Menjawab Pertanyaan dari Tim PkM

Lalu setelah mendapat pemahaman tentang komponen yang digunakan pada PLTS secara langsung, komponen-komponen tersebut dirakit dengan komponen-komponen lainnya. Setelah semua terpasang, selanjutnya dicoba untuk menyalakan lampu untuk melihat perubahan energi sinar matahari menjadi energi listrik. 


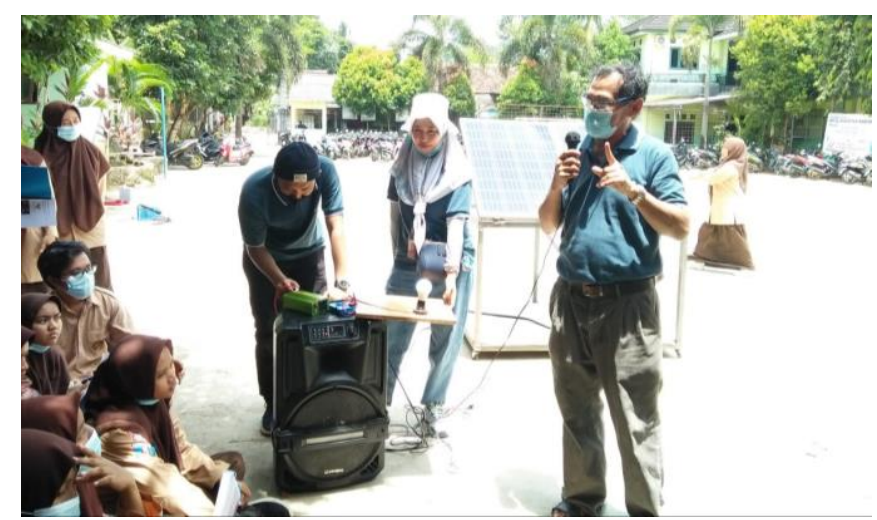

Gambar 9. Sesin Tanya Jawab dengan Tim PkM

Selain melihat dan menymak penjelasan mengenai pemasangan dan cara kerja dari PLTS Portable tersebut, siswa siswi MA Al-Khairiyah Rancaranji juga diminta untuk menghitung berapa besar arus dan daya yang dihasikan sesuai data yang telah didapatkan pada saat uji coba.

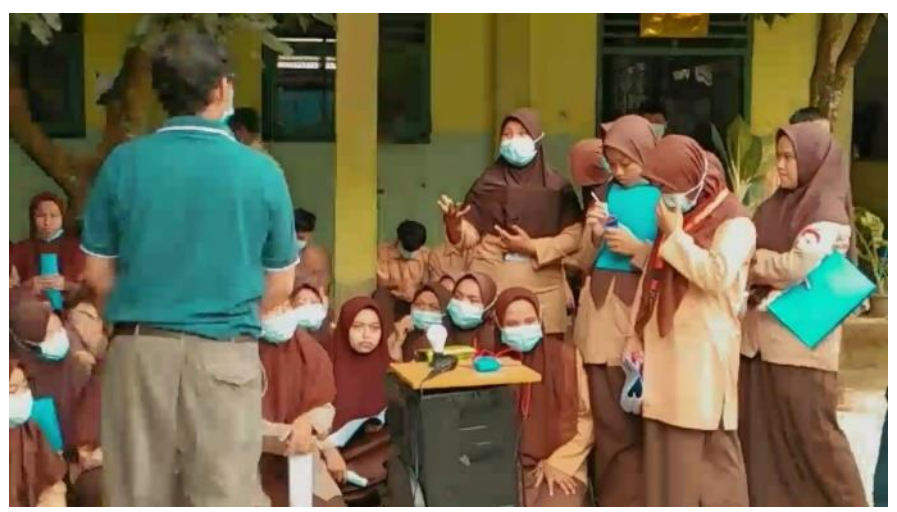

Gambar 10. Diskusi dan Tanya Jawab Protoype PLTS Portable

\subsection{Penutup}

Kegiatan PkM ini diakhiri dengan penyerahan Protoype PLTS Portable kepada Mitra PkM melalui Guru, Civitas dan Siswa Siswi MA Al-Khairiyah. Dimana Prototype PLTS Portable tersebut dibuat dengan kapasitas 100 wp. Menggunakan modul surya berjenis Polycristaline yang dipasang secara paralel. Masing masing modul surya memilki kapasitas $50 \mathrm{wp}$. Kemudian menggunakan komponen Batterai berkapasitas $100 \mathrm{Ah}$, inverter 350, controller, dan beban lampi DC dan AC 9 watt. 

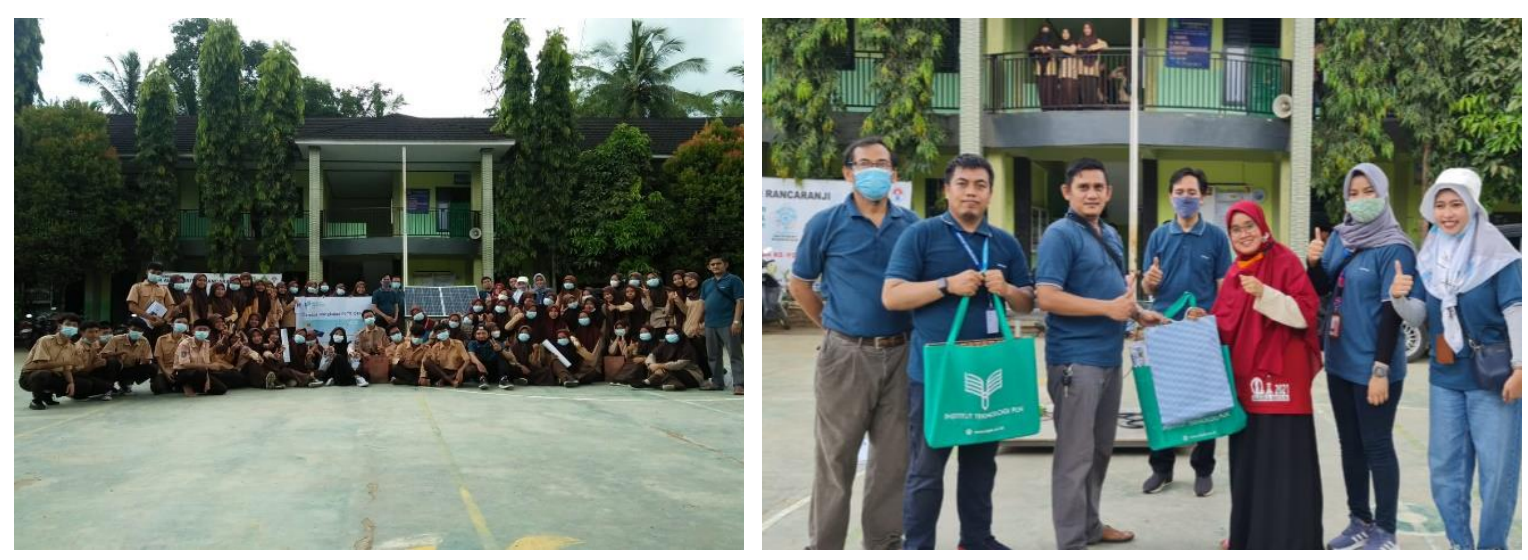

Gambar 11. Penutupan Kegiatan PkM dan Penyerahan Cindera Mata Pada Mitra

\section{KESIMPULAN}

Berdasarkan kegiatan yang telah tim PkM IT-PLN lakukan di MA Al-Khairiyah Rancaranji dengan hasil pertemuan adalah kegiatan pengabdian kepada masyarakat khususnya civitas MA AlKhairiyah Rancaranji. Kegiatan tersebut berupa:

1. Pembelajaran tentang energi baru terbarukan untuk memperkenalkan potensi energi baru terbarukan yang ada di indonesia

2. Pelatihan / Workshop pemasangan komponen-komponen pembangkit listrik tenaga surya.

3. Pemasangan PLTS Portable sebagai prortype pembelajaran dan penerapan langsung tentang pemanfaatan energi baru terbarukan yang berupa sinar matahari

4. Uji coba PLTS Portable dengan menggunakan beban DC Lampu LED 9 Watt

Dari kegiatan tersebut dapat diketahui bahwa siswa-siswi MA Al-Khairiyah Rancaranji sangat antusias dalam mengenal tentang energi baru terbarukan dan dapat menerapkannya di lingkungan sekitar.

\section{SARAN}

Pada kegiatan pengabdian selanjutnya kami menyarankan perlu kegiatan yang berkesinambungan, adanya pendampingan agar edukasi serta transfer teknologi yang sudah dilakukan dapat benar-benar terkontrol serta termonitor dengan baik, yang pada akhirnya masyarakat dapat merasakan manfaatnya.

\section{UCAPAN TERIMA KASIH}

Dalam penyusunan dan pelaksanaan kegiatan Pengabdian Kepada Masyarakat ini kami ingin mengucapkan terima kasih kepada institusi dimana kami mengabdi yaitu Institut Teknologi PLN yang mendukung terlaksananya kegiatan PKM ini. Kami juga ingin menyampaikan terima kasih kepada Kepala sekolah MA Al-Khairiyah Rancaranji beserta guru-guru dan siswa/I yang telah memberikan sarana dan prasarana, serta antusias dan sambutan yang sangat baik sehingga kegiatan PKM ini dapat terlaksana. Tak lupa juga kami ucapkan terima kasih kepada mahasiswa-mahasiswa yang terlibat dalam membantu persiapan dan pelaksanaan kegiatan ini.

\section{DAFTAR PUSTAKA}

[1] RUPTL. 2019. Rencana Usaha Penyedia Tenaga Listrik (RUPTL) 2019-2028. Diakses dari : https://web.pln.co.id/stakeholder/ruptl 
[2] Badan Standardisasi Nasional, Persyaratan Umum Instalasi Listrik 2000 (PUIL 2000): Amandemen 1.

[3] Christiono, C., Samsurizal, S., Pratama, R., Ratnasari, T., \& Fikri, M. 2019. Penyuluhan Pemanfaatan Energi Terbarukan (PLTS) di SMP IT Almaka Jakarta. TERANG, 2(1), 10- 15.

[4] Azzahra, S., Christiono, C., Samsurizal, S., Fikri, M., Ratnasari, T., Putra, R. P., \& Damiri, D. J. 2019. Pemasangan Lampu Jalan Berbasis Solar Cell untuk Penerangan Jalan di Desa Cilatak Ciomas. TERANG, 1(2), 137-143.

[5] Samsurizal, S., Makkulau, A., \& Christiono, C. 2018. Analisis Pengaruh Sudut Kemiringan Terhadap Arus Keluaran Pada Photovoltaic Dengan Menggunakan Regretion Quadratic Method. Energi \& Kelistrikan, 10(2), 137-144.

[6] Makkulau, A., Samsurizal, Christiono. 2019. Characteristics of Temperature Changes Measurement on Photovoltaic Surfaces Against Quality of Output Current on Solar Power Plants. In 2019 International Conference on Technologies and Policies in Electric Power \& Energy (pp. 1-4). IEEE.

[7] Samsurizal, S., Christiono, C., \& Makkulau, A. 2019. Evaluasi Sudut Kemiringan Terhadap Pengaruh Irradiance Pada Array Photovoltaic Jenis Monocristalline. Setrum: Sistem KendaliTenaga-elektronika-telekomunikasi-komputer, 8(1), 28-34.

[8] Indra., Z, dan Kamil, I., 2011 Analisis Sistem Instalasi Listrik Rumah Tinggal dan Gedung untuk Mencegah Bahaya Kebakaran, Jurnal Ilmiah Elite Elektro, Vol. 2, No. 1, Maret 2011: 40-44.

[9] Joewono, A., dan Tim Abdimas Jurusan Teknik Elektro, 2014. Penyuluhan dan Pelatihan Kelistrikan Di Rumah Tangga, Universitas Katolik Widya Mandala Surabaya

[10] Rifai, A., 2014, Buku Pintar Mengatasi Listrik di Rumah, Gema Buku Nusantara, Bandung.

[11] Timotius, Chris. 2009. "Perancangan dan Pembuatan Pembangkit Listrik Tenaga Surya". Jurusan Pendidikan Teknik Elektro, Fakultas Pendidikan Teknologi dan Kejuruan, Universitas Pendidikan Indonesia.

[12] Azzahra, S., Samsurizal, S., Christiono, C., \& Fikri, M. 2020. Pemasangan Lampu Jalan dan Pembangunan Pembangkit Listrik Berbasis Solar Cell Sebagai Prototype Pembelajaran Energi Terbarukan Di MA Al-Khairiyah Rancaranji. TERANG, 3(1), 100-105.

[13] Samsurizal, Husada. H, Makkulau, A. \& Christiono 2020. Perencanaan Pembangkit Listrik Tenaga Surya (PLTS) Terpusat Di Kecamatan Embaloh Hulu. EPSILON: Journal of Electrical Engineering and Information Technology, 18(2), 41-49. 